\title{
Prevalence and survival of escaped European seabass Dicentrarchus labrax in Cyprus identified using genetic markers
}

\author{
C. Brown ${ }^{1, *}$, D. Miltiadou ${ }^{1}$, C. S. Tsigenopoulos ${ }^{2}$ \\ ${ }^{1}$ Department of Agricultural Sciences, Biotechnology and Food Science, Cyprus University of Technology, PO Box 50329, \\ Limassol 3603, Cyprus \\ ${ }^{2}$ Institute of Marine Biology, Biotechnology and Aquaculture (IMBBC), Hellenic Centre for Marine Research (HCMR), \\ PO Box 2214, 71500 Heraklion, Crete, Greece
}

\begin{abstract}
The escape of European seabass Dicentrarchus labrax (L.) from fish farms is considered to be a widespread problem in the Mediterranean area, where this species is produced in large quantities in offshore cages. Whilst estimates of the number of escaped seabass in the wild have been made previously, the actual distribution, long-term survival and the potential effects on native populations remain largely unknown. This study characterises the genetic profiles of all contemporary and some historic aquaculture sources of European seabass in Cyprus and uses these profiles to identify escaped fish in seabass collected from the wild around the island. Significant differences in the microsatellite and mitochondrial DNA marker profiles were found between farmed and wild fish. The number of escapees identified was $15 \%$ of the total number of wild-caught fish sampled. However, escapees were not equally distributed; at one location $\sim 70 \%$ of wild-caught fish were escapees while in other areas escapees only accounted for up to $4 \%$. Escapees were present in all size classes of fish, but the majority were of commercial size (300-500 g) typical of seabass farmed in seacages. This indicates that they may have escaped recently and during normal aquaculture operations as no escape event was reported in the course of the study. Two large, egg-bearing females and some juvenile fish were also classified as escapees, which suggests that long-term survival and interbreeding with wild fish is possible in Cypriot waters.
\end{abstract}

KEY WORDS: Aquaculture impacts · Introgression - Interbreeding - Genetic identification · Microsatellites $\cdot$ Mitochondrial DNA

\section{INTRODUCTION}

The escape of fish from sea-based aquaculture installations is recognised as a problem due to the potential impact of cultured fish on wild populations in terms of disease (Johansen et al. 2011), competition for food (Abrantes et al. 2011) and interbreeding (Bourret et al. 2011). Cultured fish may be genetically different from wild counterparts as they may originate from other geographic areas and, as a population, may have experienced founder effects, genetic drift, domestication and directional selection as part of the

\footnotetext{
*Corresponding author: cbrown@aquabiogen.com
}

farming process (Ferguson et al. 2007). The interaction of wild and cultured fish has been studied predominantly in salmonids (reviewed by Jonsson \& Jonsson 2006) as they form the primary aquaculture species in terms of seacage production; however, any species reared in sea-based cages or pens can potentially escape and interact with wild conspecifics. Interbreeding between wild and farmed salmon (termed 'introgression') has been shown to occur frequently (Fleming et al. 2000), resulting in pronounced changes to the genetic characteristics of the wild population (McGinnity et al. 2003, Bourret et al. 2011).

() The authors 2015. Open Access under Creative Commons by Attribution Licence. Use, distribution and reproduction are unrestricted. Authors and original publication must be credited. 
European seabass Dicentrachus labrax (L.) typically spend 12-18 mo in seacages for ongrowing, and significant numbers of fish can escape when seacages are damaged by weather, accidents, predators, wear or vandalism (Jackson et al. 2012). Seabass display frequent net exploratory behaviour and are very quick to escape as large groups when opportunities arise (Papadakis et al. 2013). There are also frequent, small losses of fish during harvesting, transfers and maintenance work which could also be significant in the long term (Dempster et al. 2007). Despite frequent evidence of large numbers of escaped seabass close to fish farms (e.g. Dempster et al. 2002, ToledoGuedes et al. 2009), there are no reliable estimates of escapee frequency in the wild, of long-term survival or of the level of interaction with wild fish, although these are considered research priorities (Youngson et al. 2001, Haffray et al. 2007). An indicative estimate of escapee frequency can be found in gilthead seabream Sparus aurata-a species commonly farmed together with seabass using the same equipment and methods - which were found to approximate $13 \%$ of wild fish sampled in Croatia (Šegvić-Bubić et al. 2011). Seabass are likely to escape in numbers similar to seabream and are able to disperse further and more rapidly (Arechavala-Lopez et al. 2013), potentially increasing their ability to survive in the wild. In addition, 'escape by spawning' has been highlighted as a potentially important source of farm-origin fish from Mediterranean aquaculture as a consequence of fish increasingly being held in seacages beyond sexual maturation (Dimitriou et al. 2007, Somarakis et al. 2013).

Farmed seabass have been identified in the wild using morphology (Arechavala-Lopez et al. 2012a), fatty acid analysis (Bell et al. 2007), scale and otolith analysis (Arechavala-Lopez et al. 2012b), microsatellite DNA markers (Bahri-Sfar et al. 2005, Loukovitis et al. 2015) and mitochondrial DNA markers (Patarnello et al. 1993). However, genetic identification is considered the most informative method of determining the fate of escapees in the long term, as it is not subject to environmentally induced changes and also allows for the identification of descendants of escaped fish (Blohm et al. 2007). Genetic markers have revealed significant population structuring of seabass in the Mediterranean Sea, including confirmation of distinct populations in the East and West basins (Garcia de Leon et al. 1997, Naciri et al. 1999) and also possible further structuring of the Eastern population (Bahri-Sfar et al. 2000) located around the Levantine basin (Castilho \& Ciftci, 2005). The transfer of fish between geographical areas is common practice and could result in pronounced changes to native populations if fish escape introgression occurs (Glover et al. 2013).

In Cyprus, marine aquaculture has focused almost exclusively on European seabass and gilthead seabream production in offshore seacages (FAO 2012). There are currently 3 hatchery establishments and 9 seacage farms at 5 sites, producing seabass with a production of over 6 million fry and $\sim 1000 \mathrm{t}$ of adult seabass in 2012 (Cyprus Department of Fisheries and Marine Research 2012). Historically, both seabass and seabream were scarce in Cyprus waters but are now well-established on the southern coast of the island and are increasingly appearing in fisheries catches (FAO 2014). Cyprus is a unique location to study the escape of aquaculture stocks as there is a very small number of hatcheries and farms, the island is relatively isolated from migration of neighbouring populations ( $\sim 40$ nautical miles to the Turkish coast) and many native fish populations are overexploited and vulnerable to disturbance (FAO 2011).

The present study is one of the first studies to quantify the prevalence of escaped European seabass in the wild using microsatellite markers. With the comprehensive sampling of aquaculture and wild sources around the island we set out to provide a robust estimate of the potential impact of seabass escapes on native populations that is applicable to the aquaculture industry as a whole. Our study is also the most extensive genetic study of Cypriot seabass populations, characterising both aquaculture and native stocks for the first time.

\section{MATERIALS AND METHODS}

\section{Sample collection}

A total of 994 European seabass samples were collected for genetic analysis, and the types and sources are summarised in Table 1. Juveniles are defined here as any fish $<10 \mathrm{~g}$. All samples, i.e. caudal fin clips from adults or tail portions in the case of juveniles, were stored in $100 \%$ ethanol immediately after capture.

Wild fish were sampled from around Cyprus in 2012 and 2013 in 5 sampling areas around the island (Fig. 1). These areas were primarily designated to evenly distribute the sampling effort, with the size of each area being inversely proportional to its seabass abundance. Juvenile fish were net sampled while adult fish were caught with the help of recreational fishermen, using a variety of fishing methods includ- 
Table 1. Types of samples collected from each source and the origin of fish in each of the seabass hatcheries. Old: old broodstock, new: current broodstook or production fish

\begin{tabular}{|c|c|c|c|c|}
\hline Origin & Type & & Wild fish & \\
\hline \multirow[t]{2}{*}{$\begin{array}{l}\text { Wild fish } \\
\text { samples }\end{array}$} & $\begin{array}{l}\text { Juveniles }(<10 \mathrm{~g}) \\
\text { Adults } \\
\text { Archived wild Fren } \\
\text { Total per group }\end{array}$ & hamples & $\begin{array}{c}320 \\
151 \\
38 \\
509\end{array}$ & \\
\hline & & Hatchery 1 & Hatchery 2 & Hatchery 3 \\
\hline $\begin{array}{l}\text { ‘Old' farm } \\
\text { samples }\end{array}$ & $\begin{array}{l}\text { Juveniles }(<10 \mathrm{~g}) \\
\text { Broodstock }\end{array}$ & $\begin{array}{r}0 \\
71\end{array}$ & $\begin{array}{r}0 \\
28\end{array}$ & $\begin{array}{r}54 \\
0\end{array}$ \\
\hline $\begin{array}{l}\text { ‘New' farm } \\
\text { samples }\end{array}$ & $\begin{array}{l}\text { Juveniles }(<10 \mathrm{~g}) \\
\text { Broodstock } \\
\text { Total per hatchery } \\
\text { Total per qroup }\end{array}$ & $\begin{array}{r}0 \\
112 \\
183 \\
485\end{array}$ & $\begin{array}{r}144 \\
0 \\
172\end{array}$ & $\begin{array}{r}76 \\
0 \\
130\end{array}$ \\
\hline
\end{tabular}

ing nets, rod and line and spearfishing. A total of 471 samples were collected in Cyprus, with weights ranging from $5 \mathrm{~g}$ up to $9 \mathrm{~kg}$.

Fig. 1 also indicates the location of aquaculture facilities in Cyprus. All 3 hatchery sites operating in Cyprus were sampled in 2012 and, where possible, samples were collected from the hatchery broodstock, otherwise juveniles from the production system were sampled at random. A total of 485 samples were collected including 211 broodfish. To ensure that all of the local aquaculture production of European seabass was represented, we followed recommendations of hatchery managers and sampled older broodstock (termed 'old') as well as current broodstock or production fish (termed 'new'). Because the

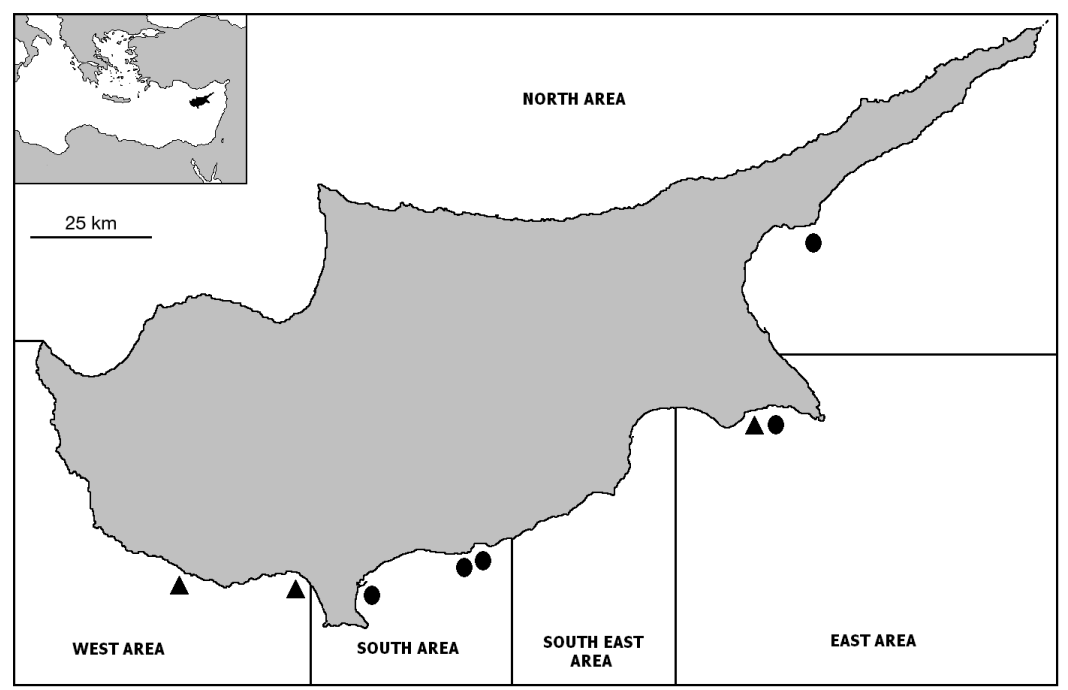

Fig. 1. Sampling areas around Cyprus and locations of aquaculture installations ( $\Delta$ hatchery site, $\bullet$ seacage site) 'new' population was suspected to mainly comprise fish imported from France several years ago, a small number $(n=38)$ of archived wild seabass DNA samples from both Atlantic and Mediterranean France were included in the analysis to confirm the origin of this population.

\section{Molecular analysis}

DNA extractions on tissue samples were performed using a salt precipitation method (Aljanabi \& Martinez 1997) on a portion of fin clip or a tail section of juvenile fish. An 11-loci multiplex PCR was used containing the following loci: DLA0060, DLA0061, DLA0086, DLA0096, DLA0044, DLA0078, DLA0051, DLA0081, DLA0089, DLA0073 and DLA0068 (Quéré et al. 2012). Fragment analysis was performed on an ABI 3730 DNA Analyzer (Applied Biosystems) and genotyping was carried out manually using STRAND software v2.4.19 (Toonen \& Hughes 2001). Raw genotype data was collated for all samples prior to alignment and determination of allele sizes. Error checking and detection of null alleles was carried out with MICROCHECKER software (van Oosterhout et al. 2004). In the whole dataset, there was 1\% missing data and whilst 7 complete loci were used as a minimum for inclusion in the analysis, only 11 samples had data for $<9$ loci.

A mitochondrial DNA marker was also chosen in order to differentiate between what were anticipated to be closely related populations. A sequence in the cytochrome $b$ gene has been shown to vary between wild and farmed populations in the Mediterranean (Patarnello et al. 1993). This marker was therefore selected to assess the characterisation of the 2 populations by identifying haplotypes in a selection of samples from both groups, totalling 143 individuals. A $462 \mathrm{bp}$ fragment of the cytochrome $b$ gene was amplified (forward primer 5' -TCG CAA ATC ATG CAC TTG TT3', reverse primer 5'-CCC CTC AAA TCC ACT GAA CT-3') in a $25 \mu \mathrm{l}$ PCR (1.5 mM MgCl $2,1 \times$ Buffer D (KAPA Biosystems), $130 \mu \mathrm{M}$ dNTPs, $0.75 \mathrm{mM}$ 
forward and reverse primers, 1 unit Taq polymerase (KAPA Biosystems). The PCR programme consisted of a denaturing step of $94^{\circ} \mathrm{C}$ for $5 \mathrm{~min}$, followed by 32 cycles of $95^{\circ} \mathrm{C}$ for $30 \mathrm{~s}, 54^{\circ} \mathrm{C}$ for $30 \mathrm{~s}$ and $72^{\circ} \mathrm{C}$ for $45 \mathrm{~s}$, with an extension period of $10 \mathrm{~min}$ at $60^{\circ} \mathrm{C}$. One single nucleotide polymorphism (SNP) in the amplified fragment was initially genotyped using the restriction enzyme FOK $I$ in a $10 \mu \mathrm{l}$ digestion reaction $(8 \mu \mathrm{l}$ PCR product, 0.5 unit enzyme [Takara Bio Europe], $1 \times$ buffer, $0.1 \% \mathrm{BSA}$ ) for $1.5 \mathrm{~h}$ at $37^{\circ} \mathrm{C}$ and visualised on an agarose gel. However, this individual locus was not conclusive so the fragment was sequenced to genotype the remaining 2 SNPs. The PCR product was purified and then sequenced using the Big Dye v.3.1 sequencing kit (Applied Biosystems) on an ABI 3100 capillary DNA Analyzer (Applied Biosystems). Sequences were constructed using Sequence Analyzer v.4 (Applied Biosystems), edited with FinchTV v.1.4 (Perkin Elmer) and aligned with AlignX (Vector NTI 7.1, Invitrogen).

\section{Statistical analysis}

Data analysis was performed using GENALEX v.6.5 (Peakall \& Smouse 2006, 2012) and GENETIX v.4.0.5.2 software (Belkhir et al. 1996) to calculate parameters including observed and expected heterozygosity, allelic richness, relatedness and population genetic differentiation $\left(F_{\mathrm{IS}}\right.$ and $\left.F_{\mathrm{ST}}\right)$ and genetic distance. Significance values were obtained by permutation and corrected using a sequential Bonferroni method for multiple tests. In addition, the principal coordinates analysis (PCoA) of genetic distances was performed using GENALEX to investigate admixture between populations based on differences in allele frequencies. Mitochondrial haplotypes were analysed using the analysis of molecular variation (AMOVA) procedure in GENALEX.
STRUCTURE v.2.3 software (Pritchard et al. 2000) was used to assign individuals to populations based on a Bayesian algorithm. Due to the potentially close nature of the 2 populations (wild and farmed), the analysis model assumed admixture of populations and correlated allele frequencies between populations, but no prior information on individual identities or sample locations was utilised. Each run of the analysis used a burn-in period of 250000 cycles and each Markov Chain Monte Carlo simulation consisted of 1 million iterations. The number of potential populations $(K)$ was increased in a step-wise manner from 1 to 9 and for each value of $K$, iterations were run 10 times to determine consistency. An assessment of $\Delta K$ (Evanno et al. 2005) based on the change in the log likelihood values was used to validate the number of populations presented by the data. In addition, farm and wild samples were analysed separately in the same manner to confirm the assignment to populations suggested by the complete analysis.

\section{RESULTS}

\section{Within group analysis: farmed fish}

The 3 farms showed some differences with respect to genetic variation (Table 2). Farm 2 showed the lowest mean number of alleles (8.45), allelic richness (6.18) and expected and observed heterozygosity ( 0.643 and 0.637, respectively). Farms 1 and 3 were comparable for both number of alleles and heterozygosity, whereas Farm 3 had a higher allelic richness (7.36), comparable even to the wild group. $F_{\text {IS }}$ was significant for all of the farm data combined but not within individual farms. The differences in these statistics between farms are attributed to the sub-structuring of the farm populations into fish from the 'old' and 'new' populations as defined in 'Materials and

Table 2. Population statistics for farmed and wild fish, with breakdowns by each farm and each wild fish sampling area, based on 11 microsatellite loci (ns: not significant, ${ }^{* *} \mathrm{p}<0.01,{ }^{* * *} \mathrm{p}<0.001$ ). Allelic richness is based on 25 samples except for the North area which is based on 3 samples

\begin{tabular}{|c|c|c|c|c|c|c|c|c|c|c|}
\hline & \multicolumn{3}{|c|}{ Farm site } & \multirow{2}{*}{$\begin{array}{c}\text { All } \\
\text { farms }\end{array}$} & \multicolumn{5}{|c|}{$\longrightarrow$ Wild sampling area - } & \multirow{2}{*}{$\begin{array}{l}\text { All } \\
\text { wild }\end{array}$} \\
\hline & Farm 1 & Farm 2 & Farm 3 & & East & South East & South & West & North & \\
\hline No. of samples (n) & 183 & 172 & 130 & 485 & 66 & 169 & 208 & 25 & 3 & 471 \\
\hline Expected heterozygosity $\left(\mathrm{H}_{\mathrm{e}}\right)$ & 0.695 & 0.643 & 0.683 & 0.695 & 0.641 & 0.725 & 0.764 & 0.712 & 0.646 & 0.744 \\
\hline Non-biased heterozygosity $\left(\mathrm{H}_{\mathrm{nb}}\right)$ & 0.697 & 0.645 & 0.685 & 0.696 & 0.646 & 0.727 & 0.764 & 0.726 & 0.776 & 0.749 \\
\hline Observed heterozygosity $\left(\mathrm{H}_{\mathrm{o}}\right)$ & 0.688 & 0.637 & 0.685 & 0.670 & 0.605 & 0.697 & 0.766 & 0.722 & 0.727 & 0.712 \\
\hline Mean no. of alleles & 8.72 & 8.45 & 9.09 & 10.90 & 8.18 & 10.09 & 10.81 & 8.00 & 3.82 & 11.45 \\
\hline Allelic richness & 6.18 & 6.18 & 7.36 & 7.27 & 6.90 & 7.92 & 7.87 & 8.00 & 3.53 & 9.57 \\
\hline$F_{\mathrm{IS}}$ & $0.012^{\mathrm{ns}}$ & $0.012^{\mathrm{ns}}$ & $0.001^{\mathrm{ns}}$ & $0.038^{* * *}$ & $0.067^{* *}$ & $0.042^{* * *}$ & $0.016^{\mathrm{ns}}$ & $0.01^{\mathrm{ns}}$ & $0.076^{\mathrm{ns}}$ & $0.049^{* * *}$ \\
\hline
\end{tabular}


methods'. By combining individuals from different origins, parameters such as number of alleles are inflated. This is confirmed by the observation that Farm 2 had the lowest incidence of sub-structuring$15 \%$ of the samples compared to $30-50 \%$ in the other farms - and consequently showed a reduced genetic variation such as allelic richness compared to the other farms. The analysis of the 2 farm populations is discussed below in 'Between group analysis: broodstock origin'.

\section{Within group analysis: wild fish}

The statistics of wild seabass samples are shown in Table 2 for each sampling area. The South and West areas show similar levels of observed heterozygosity (0.77 and 0.72), whilst in the South East and East areas this is markedly reduced $(0.70$ and 0.61 , respectively). Allelic richness, a non-biased estimator, is similar among the South, South East and West areas ( 8.0) but much reduced in the East area (6.9). The East and South East areas showed a significant departure from Hardy-Weinberg equilibrium expectations with an $F_{\mathrm{IS}}$ of 0.067 and 0.042 , respectively, probably indicating a Wahlund effect due to admixture of populations with different genetic characteristics. This admixture could signify a high number of escaped fish in these areas, and the effect was not present in the samples from other areas.

\section{Between group analysis: broodstock origin}

Confirmation of the origin of broodstocks of the farmed samples was examined by comparisons with the recognised seabass populations of Atlantic, Western Mediterranean and Eastern Mediterranean. Archived DNA samples collected from France's Mediterranean and Atlantic coasts along with wild fish from Cyprus were used in the analysis with between 17 and 25 samples per population. Pairwise $F_{\mathrm{ST}}$ values are shown in Table 3 and indicate that although significant differentiation is seen between all populations, the new farm population is closest to the French Mediterranean population. In contrast, the old farm population is closest to the wild Cypriot population. A PCoA of unbiased genetic distance between populations (Fig. 2) indicates that the 'old' broodstock is very similar to the wild Cypriot population. The 'new' broodstock group shows a poor alignment with the wild French populations on the primary axis which is probably due to genetic drift. The
Table 3. Population comparisons of wild fish (Atlantic [Atl], Western Mediterranean [WMed] and Eastern Mediterranean [EMed]) and Cypriot farm populations. Pairwise $F_{\mathrm{ST}}$ values above the diagonal and Nei unbiased genetic distance below the diagonal. A total of 17-25 samples were used per population. Significance levels after Bonferroni correction: ${ }^{*} p<0.01,{ }^{* *} p<0.005,{ }^{* * *} p<0.001$

\begin{tabular}{|lccccc|}
\hline & $\begin{array}{c}\text { France } \\
\text { (WMed) }\end{array}$ & $\begin{array}{c}\text { France } \\
\text { (Atl) }\end{array}$ & $\begin{array}{c}\text { Cyprus } \\
\text { (EMed) }\end{array}$ & $\begin{array}{c}\text { New } \\
\text { farm }\end{array}$ & $\begin{array}{c}\text { Old } \\
\text { farm }\end{array}$ \\
\hline France (WMed) & - & $0.0468^{* *}$ & $0.0625^{* *}$ & $0.0914^{* *}$ & $0.0499^{* *}$ \\
France (Atl) & $0.125^{* * *}$ & - & $0.0789^{* *}$ & $0.1521^{* *}$ & $0.0552^{* *}$ \\
Cyprus (EMed) & $0.196^{* * *}$ & $0.244^{* * *}$ & - & $0.1127^{* *}$ & $0.0282^{* *}$ \\
New farm & $0.224^{* * *}$ & $0.424^{* * *}$ & $0.315^{* * *}$ & - & $0.1118^{* *}$ \\
Old farm & $0.151^{* * *}$ & $0.160^{* * *}$ & $0.087^{*}$ & $0.308^{* * *}$ & - \\
& & & & & \\
\hline
\end{tabular}

new farm group demonstrate a loss of genetic variation at some loci-a mean $( \pm \mathrm{SE})$ unbiased expected heterozygosity of $0.620 \pm 0.051$ compared to $0.714 \pm$ 0.051 in the French Mediterranean samples - which has occurred during the farming process. This could be from repeated sampling of the population in order to form broodstock populations, perhaps over 2 or 3 generations, or from crossing with other strains. Because of these clear differences in origin and to minimise confounding the analysis with withinpopulation differentiation, the 2 farm groups will be considered separately in further analyses.

\section{Between group analysis: farmed and wild fish}

Genetic variability was greater in the wild samples compared to the farmed samples, with mean number of alleles, allelic richness, observed and expected heterozygosities all greater for the wild population ('All farm' and 'All wild' columns of Table 2). PCoA of genetic distances of all samples (Fig. 3) clearly shows that the wild samples and the new farm stocks form 2 well-separated groups, whereas the old stocks are more dispersed, with only 1 example (Farm 3) appearing close to the wild group. The escaped fish (discussed below) were also plotted in this figure and the results indicate that these fish are similar to the new farm stocks.

Due to the strong differences between these populations, the potential to assign individuals to farmed or wild was very high. Using randomised genotype data from the 2 groups indicated that $95 \%$ of samples could be assigned to the correct group. The exclusionary power of the markers used was also high, with 8 loci required for $100 \%$ exclusion in the wild group and 9 in the farmed group with the assumption of related individuals in the population. STRUCTURE 


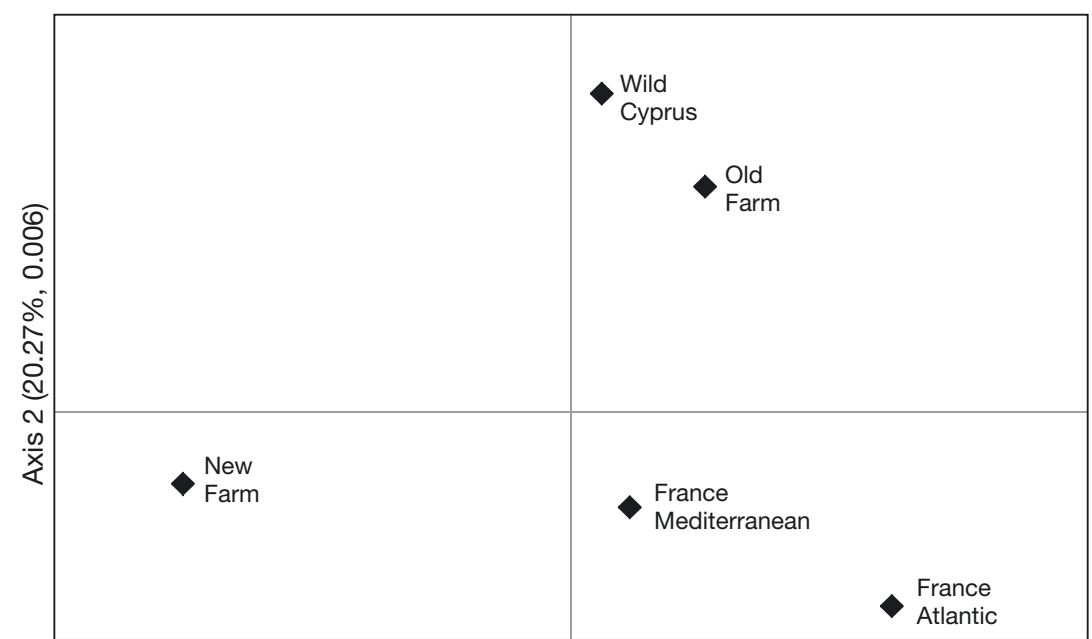

Axis $1(74.6 \%, 0.023)$

Fig. 2. Principal coordinate analysis based on the standardized covariance of Nei (1978) unbiased genetic distance between the farm populations and populations from Atlantic, West Mediterranean and East Mediterranean (wild Cyprus). A total of 17-25 samples were used per population. Axis label includes percentage of variation explained by axis and the axis Eigenvalue

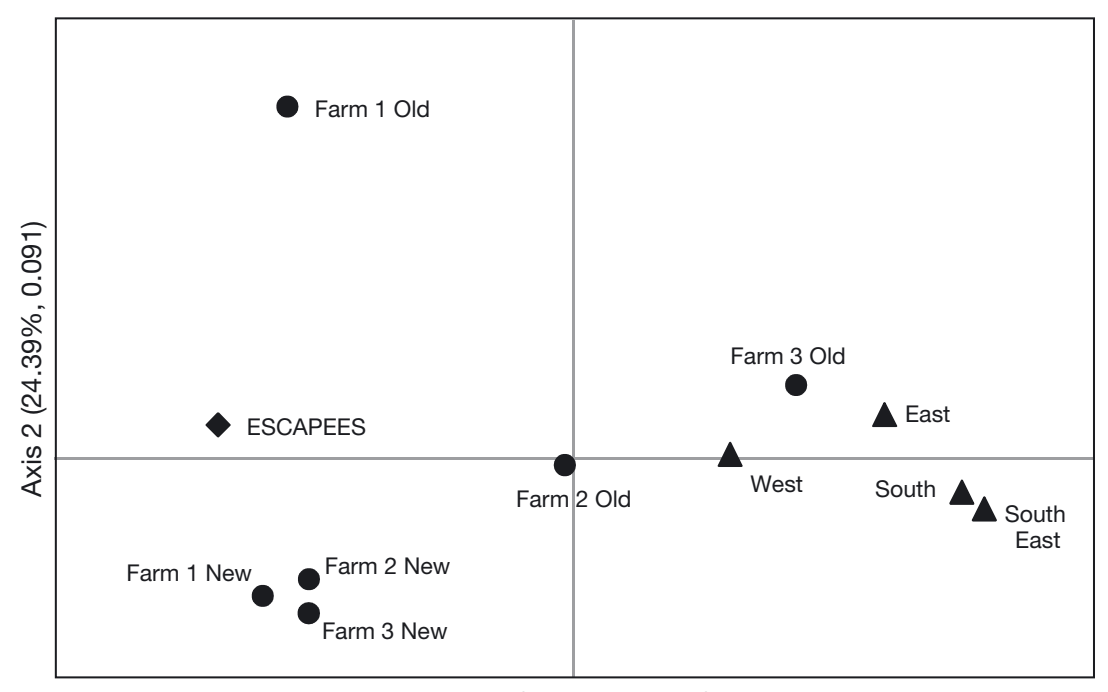

Axis $1(37.41 \%, 0.139)$

Fig. 3. Principal coordinate analysis based on the standardized covariance of Nei's unbiased genetic distance between wild $(\boldsymbol{\Delta})$ and farmed $(\bullet)$ populations. A total of 10 samples were used per population. Axis label includes percentage of variation explained by axis and the axis Eigenvalue

software was used to assign individuals to various numbers of populations with no prior assumption of origin. Using the method of Evanno et al. (2005), the $\Delta K$ statistic clearly indicated that a 2-population model was the best explanation of the data. Fig. 4 presents a graphical summary of the STRUCTURE results. The results establish the presence of 2 populations corresponding to wild and farmed fish. The assignment of individuals to the 2 populations had a high degree of confidence, with $81 \%$ of samples assigned at a probability of over $95 \%$. The assignment of individuals to populations confirms that some farmed samples are of wild Cypriot origin, corresponding precisely with the old broodstock groups determined during sampling. The old stock detected in the farms are concluded to be descendants of wildcaught broodstock utilised in the past due to their young age (3-10 yr) and the assertion of farm managers that no current stock have been captured locally.

The results also confirm the presence of a significant number of farmed fish in the wild samples, a total of 72 fish or $15 \%$. However, the geographical distribution of these escapees was heavily skewed to 3 sites close together in the Larnaca area (1 site, Pervolia, accounting for almost half of the escapees identified) where a disproportionate sampling effort was achieved due to these sites' popularity with fishermen. If samples from these 3 sites are removed (53 fish), the number of escapees is reduced to 19 fish or $\sim 4 \%$ of the total number of wild-caught samples. The size distribution of the escaped fish is shown in Fig. 5 and clearly indicates that escapees of all size classes were detected. Over $90 \%$ of the escapees were in the size range typically found in seacages (2 to $1500 \mathrm{~g}$ ), and these fish had a mean weight of $521 \mathrm{~g}$. This would suggest that escapees are likely to have been recent escapes from seacages under normal operations as no escape events were reported prior to, or during the sampling period. Larger specimens were also identified and included 3 fish at $2-3 \mathrm{~kg}$ and 2 fish $<6 \mathrm{~kg}$, with the largest being $7.5 \mathrm{~kg}$. Escapees of this age strongly indicate that long-term survival of escaped seabass is possible, thus also increasing the risk of interbreeding. In the STRUCTURE results, 11 wild fish and 12 farmed fish were not assigned to a single population with high levels of confidence $(Q \leq 0.70)$. Low-level assignment to both populations could indicate the presence of 

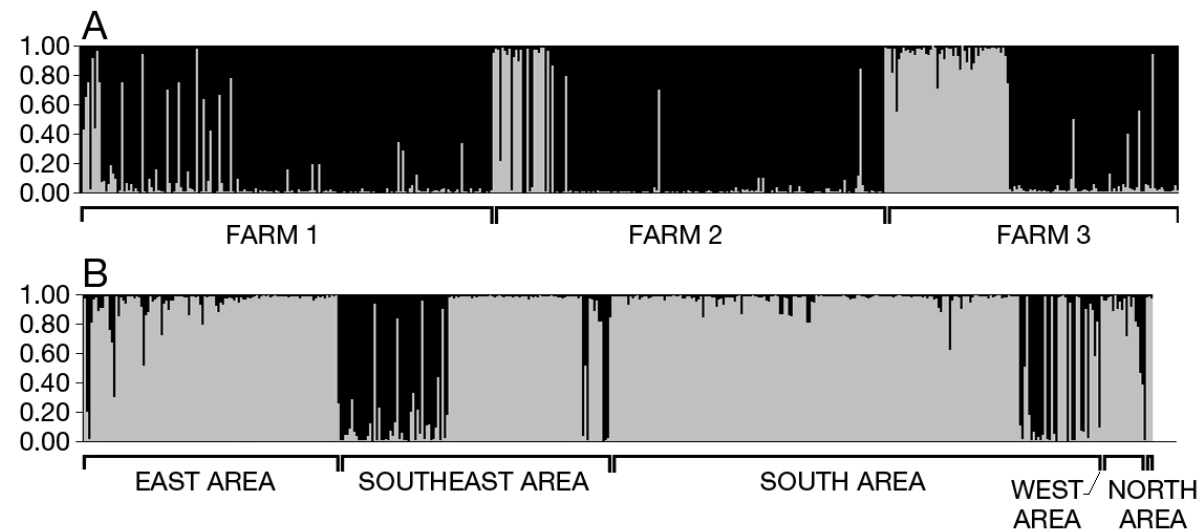

Fig. 4. Summary of STRUCTURE analysis with 2-population model. All samples were analysed together but here are separated into (A) farm and (B) wild, ordered by sampling location and collection date. Each bar represents an individual and the height of the bar is the probability of assignment to either farm origin (black) or wild origin (grey)
AMOVA test of population differentiation was highly significant $(\Phi=0.089, \mathrm{p}<0.001)$.

Whilst these markers alone could not be used to identify farmed fish, they could be used to confirm the origin of fish if the wildspecific haplogroup variations noted here are detected (haplogroups 3 and 4). A total of 22 of the escaped fish identified by their microsatellite genotypes were also sequenced at the mitochondrial SNPs and none had the wildspecific haplogroups (Fig. 6c).

\section{DISCUSSION}

The results of this study show conclusive evidence of the presence of a wild population of European seabass in Cypriot waters that is genetically distinct from fish originating from aquaculture sources. Contrary to the common perception in Cyprus that most European seabass in local waters are farm escapes, this study shows that there are native seabass and that the genetic integrity of the wild population is good. Whereas the catches of many fish species in the Eastern Mediterranean have been influenced by overfishing (FAO 2011), catches of seabass in Cyprus suggest that the population is currently expanding. Some of this increase in abundance is certainly due to the recapture of escapees after large escape events, but the frequency of these is typically quite low and cannot explain increasing annual catches over several years. The number of fish reported lost from farms is estimated to be equivalent to 1 or 2 cages every $5 \mathrm{yr}$-although exceptional weather events, such as in January 2015, can lead to the loss of several cages in a single event. Elsewhere, it has been noted that aquaculture activities may actually increase recruitment in natural populations (Dimi-

\section{Mitochondrial DNA analysis}

Analysis of the mitochondrial DNA markers indicated that little variation was found in the farmed individuals compared to their wild counterparts (Fig. 6a,b). Of the 4 haplogroups detected, farmed fish were restricted to only 2 groups, with almost $95 \%$ displaying the same group (haplogroup 1), whereas wild fish showed all 4 groups and up to $30 \%$ of individuals had polymorphisms at one or more loci. An
A

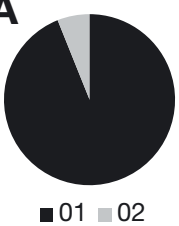

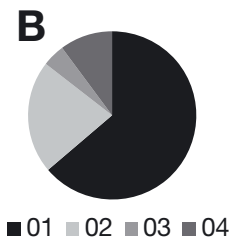

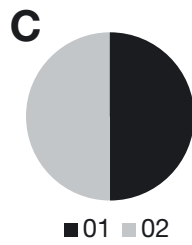

Fig. 6. Haplogroup distribution in (A) farmed seabass $(\mathrm{n}=$ $73)$, (B) wild seabass $(n=49)$ and $(C)$ escapees $(n=22)$. Four haplogroups were identified from 3 single nucleotide polymorphism (SNP) markers in the cytochrome $b$ gene 
triou et al. 2007) and this could be the situation in Cyprus. This study indicates that the areas of the southern coast with established aquaculture installations were also the areas with the highest abundance of wild seabass.

The overall number of escapes detected in the wild samples was close to $15 \%$, which is comparable to studies of other species such as gilthead seabream at $13 \%$ (Šegvić-Bubić et al. 2011) and Atlantic salmon at $20 \%$ in the Faroe Islands (Hansen et al. 1999). However, more than half of the escapees in this study were captured at or within $10 \mathrm{~km}$ of a single location, meaning that elsewhere the frequency of escapes was only $4 \%$. Due to the large number of fishermen using particular locations, the sampling effort was higher at some sites, leading to a skewing of the frequency of escapees in the dataset. The frequency of escaped fish was notably significantly higher at 1 site in particular (up to $70 \%$ of captures), suggesting that escaped fish were congregating at this point. Such aggregations of escaped seabass are typically found very close to fish farms (Dempster et al. 2007), although seabass escapees also show preferences for complex environments that offer good hunting conditions (Toledo-Guedes et al. 2009). The location, Pervolia on the southern coast close to Larnaca, is $\sim 30 \mathrm{~km}$ from the nearest aquaculture facilities both to the East and West. The area presents ideal seabass conditions, with shallow water and sand beaches and boulder areas within a few tens of metres of the shoreline and is also close to extensive areas of seagrass (Posidonia oceanica) meadows. Such an assembly of escapees could potentially have escaped together (over $60 \%$ of the fish were of the size 300-500 g) and remained together as a shoal and become established in this favourable location. Shoaling is a common behaviour of young seabass and is also noted in recently escaped fish (ArechavalaLopez et al. 2013). The duration of this shoaling behaviour after escaping in seabass is unknown, but in the long term it could have significant negative implications for wild fish if large groups of escapees are able to form breeding groups.

Fish identified as escapees represented a wide range of size classes including adults of $>6 \mathrm{~kg}$. The presence of such mature fish confirms 2 important questions regarding the long-term survival of escaped seabass; firstly, that they can survive for extended periods and, secondly, that they are capable of breeding in the wild. Interbreeding with wild stocks is much more likely in fish of such an age and size, and this was confirmed by the presence of mature eggs in both of the larger fish captured. Even the younger escapees may be capable of interbreeding, as spawning of farmed fish in seacages has been noted in other species, including cod (Jørstad et al. 2008) and seabream (Somarakis et al. 2013). Female seabass are considered unlikely to mature in the normal timescale of seacage residency as they mature at 3 years of age (Carrillo et al. 1995). However, studies in Cyprus indicate that substantial numbers of seabass females do mature in the seacages under normal farming conditions (Brown et al. 2014) and this represents a potential source of escape (ICES 2006). Egg production from such spawning could be very significant but survival is likely to be extremely low, particularly beyond the larval stage, and the true impact on natural populations is hard to determine (Uglem et al. 2012).

The presence of wild-type genotypes in the broodstocks of all farms suggests that broodfish were sourced locally in the past, perhaps in the previous generation given the age and history of the sampled fish, but have been largely replaced in the hatcheries by stocks sourced from other countries (such as France) as a means of improving performance (C. Brown pers. obs.). The reduced genetic variability of these new stocks was apparent in all the farms and implies they have been obtained from aquaculture sources rather than the wild (Loukovitis et al. 2015). Such a trend could have implications for protecting the wild gene pool if significant numbers of seabass escape from aquaculture sites in the future (Bourret et al. 2011). The high level of genetic differentiation between these fish and native populations (Table 3) is likely to increase the level of genetic change resulting from introgression (Glover et al. 2013). Taranger et al. (2015) concludes that the risk of genetic introgression is considered high, with a frequency of escapees $>10 \%$ and low risk $<4 \%$. The results of the present study suggest that in Cyprus the risk of introgression is in general moderate, but at certain locations there is a very high risk of interbreeding due to the high number of escapees present. These results also show that a certain proportion of escapees are able to survive long-term and potentially breed over several years, further increasing the rate of introgression. A small number of fish were noted as potential hybrids of wild and farmed fish due to low assignment values to both populations, which could be considered as evidence of interbreeding. However, the close nature of some 'old' farm stock and the wild population from which it originated means that low or mixed assignment to populations is not necessarily evidence of interbreeding. Rather, this reflects the limitations of the cluster- 
ing methodology when closely related populations are involved and the number of markers is limited (Waples \& Gaggiotti 2006). Whilst we conclude that there is no evidence of introgression of farmed genotypes in the wild population at present, the move by all the local hatcheries to fish of French origin means that such evidence may become clearer in the future.

The detection of such long-term escapees could only be achieved with genetic tests, as over the long term, many of the physiological methods of identification would be indistinguishable from the wild fish (Blohm et al. 2007). Importantly, this study was able to sample a broad range of aquaculture sources so that a complete picture of current and historic genetic profiles was obtained. The assignments of individuals to the farmed and wild groups using STRUCTURE was achieved with a very high level of confidence and was confirmed by the high $F_{\mathrm{ST}}$ between groups. Additionally, the mitochondrial marker produced 2 wild-specific haplogroups that validated the identification of wild fish, but the marker alone was not sufficient to discriminate farmed fish as it has in other populations (Patarnello et al. 1993). The significant departure from HW equilibrium in the East samples could not be resolved here, as the analysis-including the mitochondrial DNA marker-indicated that the overwhelming majority are wild fish. However, neutral markers may underestimate introgression in certain circumstances, especially if gene flow is derived from ancestral or multiple populations (Glover et al. 2011). This could be the case in Cyprus as the data presented here proves that hatcheries, until recently, have been using broodstocks of local origins. The low genetic distance between Farm 3 and the wild group (Fig. 3) could be a factor in the underestimation of escapees in the East area, where this farm is also located. Further research into this problem would require additional discriminatory tests, such as scale analysis (ArechavalaLopez et al. 2012b) to validate the origin of fish.

Whilst the native population of European seabass in Cyprus is so far broadly unaffected by the impact of aquaculture escapees, further research is needed to monitor the situation. There is a potential risk of introgression into wild populations in certain locations and this risk could be influenced by the numbers of fish escaping from aquaculture. As no reports of escapes were noted before or during this study, most fish identified as escapees are assumed to have come from low-level (non-reported) events during routine operations. However, since the end of this study, a large-scale escape event during poor weather in January 2015 has released several hun- dred tonnes of fish (seabass and seabream) from all of the local farms. The impact of such severe events on the native population needs to be investigated and the data presented here has established a baseline for such work.

Acknowledgements. This research was supported by the

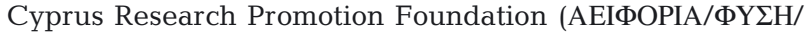
0609/BE02) with co-funding from the Republic of Cyprus and the EU Regional Development Fund. The authors thank the hatchery companies for participating in the sampling programme and all of the recreational fishermen and colleagues in Cyprus who contributed samples and information to this research.

\section{LITERATURE CITED}

Abrantes KG, Lyle JM, Nichols PD, Semmensa JM (2011) Do exotic salmonids feed on native fauna after escaping from aquaculture cages in Tasmania, Australia? Can J Fish Aquat Sci 68:1539-1551

Aljanabi SM, Martinez I (1997) Universal and rapid saltextraction of high quality genomic DNA for PCR-based techniques. Nucleic Acids Res 25:4692-4693

Arechavala-Lopez P, Sanchez-Jerez P, Bayle-Sempere JT, Sfakianakis DG, Somarakis S (2012a) Morphological differences between wild and farmed Mediterranean fish. Hydrobiologia 679:217-231

Arechavala-Lopez P, Sanchez-Jerez P, Bayle-Sempere JT, Sfakianakis DG, Somarakis S (2012b) Discriminating farmed gilthead sea bream Sparus aurata and European sea bass Dicentrarchus labrax from wild stocks through scales and otoliths. J Fish Biol 80:2159-2175

Arechavala-Lopez P, Sanchez-Jerez P, Fernandez-Jover D, Bayle-Sempere JT, Uglem I, Dempster T (2013) Postescape behaviours of farmed seabream and seabass. In: Prevent Escape project compendium. Chapter 4.5. Commission of the European Communites, 7th Research Framework Program. www.preventescape.eu

> Bahri-Sfar L, Lemaire C, Ben Hassine OK, Bonhomme F (2000) Fragmentation of sea bass populations in the western and eastern Mediterranean as revealed by microsatellite polymorphism. Proc R Soc B 267:929-935

Bahri-Sfar L, Lemaire C, Chatain B, Divanach P, Ben Hassine OK, Bonhomme F (2005) Impact de l'élevage sur la structure génétique des populations méditerranéennes de Dicentrarchus labrax. Aquat Living Resour 18: 71-76

Belkhir K, Borsa P, Chikhi L, Raufaste N, Bonhomme F (1996-2004) GENETIX 4.05, logiciel sous Windows TM pour la génétique des populations. Laboratoire Génome, Populations, Interactions, CNRS UMR 5000, Université de Montpellier II, Montpellier. http://kimura.univ-montp2. fr/genetix/

Bell JG, Preston T, Henderson RJ, Strachan F, Bron JE, Cooper K, Morrison DJ (2007) Discrimination of wild and cultured European seabass (Dicentrarchus labrax) using chemical and isotopic analysis. J Agric Food Chem 55: 5934-5941

Blohm D, Bonhomme F, Carvalho G, Crosetti D and others (2007) Assessment of tools for identifying the genetic origin of fish and monitoring their occurrence in the wild. 
In: Svåsand T, Crosetti D, García-Vázquez E, Verspoor E (eds) Genetic impact of aquaculture activities on native populations. Genimpact final scientific report (EU contract n. RICA-CT-2005-022802), p 128-134. www.imr.no/ genimpact/en

Bourret V, O'Reily PT, Carr JW, Berg PR, Bernatchez L (2011) Temporal change in genetic integrity suggests loss of local adaptation in a wild Atlantic salmon (Salmo salar) population following introgression by farmed escapees. Heredity 106:500-510

Brown C, Miltiadou D, Anastasiades G (2014) Precocious female maturation in seacage populations of European seabass (Dicentrarchus labrax) in Cyprus. Aquaculture Europe 2014, Donostia San Sebastian, Spain, 14-17 October, European Aquaculture Society, doi:10.13140/ 2.1.3300.6087

Carrillo M, Zanuy S, Prat F, Cerdá J, Ramos J, Mañanós E, Bromage N (1995) Sea bass (Dicentrarchus labrax). In: Bromage NR, Roberts RJ (eds) Broodstock management and egg and larval quality. Blackwell Science, Oxford, p 138-168

Castilho R, Ciftci Y (2005) Genetic differentiation between close eastern Mediterranean Dicentrachus labrax (L.) populations. J Fish Biol 67:1746-1752

Cyprus Department of Fisheries and Marine Research (2012) Annual Report 2012. Dept of Fisheries and Marine Research, Ministry of Agriculture, Rural Development and Environment, Nicosia. www.moa.gov.cy/moa/dfmr/ dfmr.nsf/index_en/index_en?OpenDocument

Dempster T, Sanchez-Jerez P, Bayle-Sempere JT, GiménezCasalduero F, Valle C (2002) Attraction of wild fish to sea-cage fish farms in the south-western Mediterranean Sea: spatial and short-term temporal variability. Mar Ecol Prog Ser 242:237-252

Dempster T, Moe H, Fredheim A, Jensen $\varnothing$, Sanchez-Jerez $\mathrm{P}$ (2007) Escapes of marine fish from sea-cage aquaculture in the Mediterranean Sea: status and prevention. In: Briand $F$ (ed) Impact of mariculture on coastal ecosystems, Lisbon, 21-24 February 2007. CIESM Workshop Monographs No. 32, CIESM Mediterranean Science Commission, Monaco, p 55-60

Dimitriou E, Katselis G, Moutopoulos DK, Akovitiotis C, Koutsikopoulos C (2007) Possible influence of reared gilthead sea bream (Sparus aurata, L.) on wild stocks in the area of the Messolonghi lagoon (Ionian Sea, Greece). Aquacult Res 38:398-408

Evanno G, Regnaut S, Goudet J (2005) Detecting the number of clusters of individuals using the software STRUCTURE: a simulation study. Mol Ecol 14:2611-2620

FAO (Food and Agriculture Organization of the United Nations) (2011) Review of the state of the world marine fisheries resources. Chapter B4: Mediterranean and Black Sea. FAO Fish Aquacult Tech Pap 569, FAO, Rome, p 77-92

FAO (2012) National aquaculture sector overview-Cyprus. National aquaculture sector overview fact sheets. Text by Papadopoulos V. In: FAO Fisheries and Aquaculture Department [online], Rome, updated 12 October 2012. www.fao.org/fishery/statistics/global-capture-production/ query/en (accessed Sep 2014)

FAO (2014) Cyprus fisheries capture data 2000-2012. www. fao.org/figis/servlet/TabSelector (accessed Sep 2014)

Ferguson A, Fleming A, Hindar K, Skaala Ø, McGinnity $P$, Cross T, Prodöhl P (2007) Farm escapes. In: Verspoor E, Stradmeyer L, Nielsen JL (eds) The Atlantic salmon- genetics, conservation and management, Chapter 12. Blackwell Publishing, Oxford, p 357-398

Fleming IA, Hindar K, Mjølnerød IB, Jonsson B, Balstad T, Lamberg A (2000) Lifetime success and interactions of farm salmon invading a native population. Proc R Soc B 267:1517-1523

Garcia de Leon FJ, Chikhi L, Bonhomme F (1997) Microsatellite polymorphism and population subdivision in natural populations of European sea bass Dicentrarchus labrax (Linnaeus, 1758). Mol Ecol 6:51-62

Glover KA, Dahle G, Jørstad KE (2011) Genetic identification of farmed and wild Atlantic cod, Gadus morhua, in coastal Norway. ICES J Mar Sci 68:901-910

Glover KA, Pertoldi C, Besnier F, Wennevik V, Kent M, Skaala $\varnothing$ (2013) Atlantic salmon populations invaded by farmed escapees: quantifying genetic introgression with a Bayesian approach and SNPs. BMC Genet 14:74-93

Haffray P, Tsigenopoulos CS, Bonhomme F, Chatain B and others (2007) European seabass-Dicentrarchus labrax. In: Svåsand T, Crosetti D, García-Vázquez E, Verspoor E (eds) Genetic impact of aquaculture activities on native populations. Genimpact final scientific report (EU contract n. RICA-CT-2005-022802), p 40-46. www.imr.no/ genimpact/en

Hansen LP, Jacobsen JA, Lund RA (1999) The incidence of escaped farmed Atlantic salmon, Salmo salar L., in the Faroese fishery and estimates of catches of wild salmon. ICES J Mar Sci 56:200-206

ICES (International Council for the Exploration of the Sea) (2006) Risk analysis of the potential interbreeding of wild and escaped farmed sea bass. Annex 7. Report of the Working Group on Environmental Interactions of Mariculture (WGEIM), 24-26 April 2006, Narragansett, RI, USA. ICES, Copenhagen, p 128-143

Jackson D, Drumm A, McEvoy S, Jensen $\varnothing$ and others (2012) A pan-European evaluation of the extent, causes and cost of escape events from sea-cage fish farming. In: Prevent Escape project compendium. Chapter 2. Commission of the European Communities, 7th Research Framework Program. www.preventescape.eu

> Johansen LH, Jensen I, Mikkelsen H, Bjørn PA, Jansen PA, Bergh $\varnothing$ (2011) Disease interaction and pathogens exchange between wild and farmed fish populations with special reference to Norway. Aquaculture 315:167-186

Jonsson B, Jonsson N (2006) Cultured Atlantic salmon in nature: a review of their ecology and interaction with wild fish. ICES J Mar Sci 63:1162-1181

> Jørstad KE, Van der Meeren T, Paulsen OI, Thomsen T, Thorsen A, Svåsand T (2008) 'Escapes' of eggs from farmed cod spawning in net pens: recruitment to wild stocks. Rev Fish Sci 16:285-295

Loukovitis D, Ioannidi B, Chatzaplis D, Kotoulas G, Magoulas A, Tsigenopoulos CS (2015) Loss of genetic variation in Greek hatchery populations of the European seabass (Dicentrarchus labrax L.) as revealed by microsatellite DNA analysis. Mediterr Mar Sci 16:197-200

McGinnity P, Prodöhl P, Ferguson A, Hynes R and others (2003) Fitness reduction and potential extinction of wild populations of Atlantic salmon, Salmo salar, as a result of interactions with escaped farm salmon. Proc R Soc B 270: 2443-2450

Naciri M, Lemaire C, Borsa P, Bonhomme F (1999) Genetic study of the Atlantic/Mediterranean transition in sea bass (Dicentrarchus labrax). J Hered 90:591-596

Papadakis IE, Papadakis VM, Glaropoulos A, Kentouri M 
(2013) The escape-related behaviour of European seabass (Dicentrarchus labrax) and gilthead seabream (Sparus aurata). In: Prevent Escape project compendium. Chapter 3.3. Commission of the European Communities, 7th Research Framework Program. www.preventescape.eu

Patarnello T, Bargelloni L, Caldara F, Colombo L (1993) Mitochondrial DNA sequence variation in the European sea bass, Dicentrarchus labrax L. (Serranidae): evidence of differential haplotype distribution in natural and farmed populatinos. Mol Mar Biol Biotechnol 2: 333-337

Peakall R, Smouse PE (2006) GENALEX 6: genetic analysis in Excel. Population genetic software for teaching and research. Mol Ecol Notes 6:288-295

> Peakall R, Smouse PE (2012) GENALEX 6.5: genetic analysis in Excel. Population genetic software for teaching and research-an update. Bioinformatics 28:2537-2539

Pritchard JK, Stephens M, Donnelly P (2000) Inference of population structure using multilocus genotype data. Genetics 155:945-959

Quéré N, Desmarais E, Tsigenopoulos CS, Belkhir K, Bonhomme F, Guinand B (2012) Gene flow at major transitional areas in sea bass (Dicentrarchus labrax) and the possible emergence of a hybrid swarm. Ecol Evol 2: 3061-3078

Šegvić-Bubić T, Lepen I, Trumbić Ž, Ljubković J and others (2011) Population genetic structure of reared and wild gilthead sea bream (Sparus aurata) in the Adriatic Sea inferred with microsatellite loci. Aquaculture 318:309-315

Somarakis S, Pavlidis M, Saapoglou C, Tsigenopoulos CS, Dempster T (2013) Evidence for 'escape through spawning' in large gilthead sea bream Sparus aurata reared

Editorial responsibility: Dean Jerry,

Townsville, QLD, Australia in commercial sea-cages. Aquacult Environ Interact 3: 135-152

Taranger GL, Karlsen Ø, Bannister RJ, Glover KA and others (2015) Risk assessment of the environmental impact of Norwegian Atlantic salmon farming. ICES J Mar Sci 72: 997-1021

Toledo-Guedes K, Sánchez-Jerez P, González-Lorenzo G, Hernández AB (2009) Detecting the degree of establishment of a non-indigenous species in coastal ecosystems: sea bass Dicentrarchus labrax escapes from sea cages in Canary Islands (Northeastern Central Atlantic). Hydrobiologia 623:203-212

Toonen RJ, Hughes S (2001) Increased throughput for fragment analysis on ABI Prism 377 automated sequencer using a membrane comb and STRand Software. Biotechniques 31:1320-1324

> Uglem I, Knutsen $\varnothing$, Kjesbu OS, Hansen $\varnothing \mathrm{J}$ and others (2012) Extent and ecological importance of escape through spawning in sea-cages for Atlantic cod. Aquacult Environ Interact 3:33-49

van Oosterhout C, Hutchinson WF, Wills DPM, Shipley P (2004) MICRO-CHECKER: software for identifying and correcting genotyping errors in microsatellite data. Mol Ecol Notes 4:535-538

> Waples RS, Gaggiotti O (2006) What is a population? An empirical evaluation of some genetic methods for identifying the number of gene pools and their degree of connectivity. Mol Ecol 15:1419-1439

Youngson AF, Dosdat A, Saroglia M, Jordan WC (2001) Genetic interactions between marine finfish species in European aquaculture and wild conspecifics. J Appl Ichthyol 17:153-162

Submitted: January 2, 2015; Accepted: May 26, 2015 Proofs received from author(s): June 26, 2015 